\title{
Trends in Robotics-related Curricula of Elementary, Middle, and High Schools in Korea: A Review of the 2007, 2011 and 2015 Revised Curricula
}

\author{
Sung Ae Kim \\ Department of Practical Arts, Jeonju National University of Education, Korea
}

Copyright@2019 by authors, all rights reserved. Authors agree that this article remains permanently open access under the terms of the Creative Commons Attribution License 4.0 International License

\begin{abstract}
The purpose of this study is to analyze the trends and characteristics of the educational objectives and contents related to robotics in the curricula for elementary, middle, and high school students in Korea. Based on the revised national curriculum, this study analyzed the trends and characteristics of educational objectives (or achievement criteria) and their contents. The results of this study are as follows. First, the word "robot" was found among the "Practical Arts" subject taught in elementary schools, within that of "Technology and Home Economics" in middle schools, and within "Technology and Home Economics" and "Engineering technology" in high schools. In the recently revised curriculum, Informatics included robotics-related terms such as "microcontroller" and "in/output device" for the first time. After the word "robot" was first used in the 2007 revised national curriculum for "Engineering technology", which is an elective subject in high schools, the number of robotics-related terms gradually expanded in the stated educational objectives and contents characterizing the curricula for elementary, middle, and high schools. Second, elementary and middle schools have focused on both lower and higher order thinking skills in robotics-related educational objectives, while high schools have focused only on lower order thinking skills. In addition, the types of knowledge covered by the educational objectives were mostly classified as conceptual and procedural. Third, the robotics-related educational contents in elementary schools increased independent of electronics technology, and a greater emphasis was placed on software education. In middle schools, robotics-related educational contents were included in those related to manufacturing technology, but not in the recently revised curriculum. Mechanical Engineering was the first elective subject in high schools to include "robot" in the automation section of the curriculum, but such contents were not included in the recently revised curriculum. Conversely, in high schools, the subject area of "Technology and Home Economics" included more
\end{abstract}

contents on advanced technology in the future technology section. The curriculum for Informatics, the first subject to include robotics-related contents, comprised physical computing. As described above, robotics-related educational objectives and contents were updated to keep pace with changes in society, but lacked consistency in their continuity and sequentiality. Since robotics technology is considered essential for the future, the related curricula in elementary, middle, and high schools must be improved to ensure continuity and sequentiality.

Keywords Robotics-related Curricula, Korea's National Curriculum, Practical Arts Education, Technology and Engineering Education, Informatics Education

\section{Introduction}

Robotics is recognized as a crucial form of advanced technology for the fourth industrial revolution, in addition to AI (Artificial Intelligence), the IoT (Internet of Things), Big Data, AR (Augmented Reality), and VR (Virtual Reality) [1]-[3]. Countries around the world, including Korea, the United States, Japan, and China, have consistently announced new policies related to robotics [4], [5] because the robotics industry is expanding to become a future growth engine for the fourth industrial revolution, and is a key element in the development of various industries [6]. Robotics has become increasingly emphasized in both industrial and educational settings. In terms of education, robotics can improve students' higher order thinking skills such as knowledge integration, problem-solving, and creativity, as well as their capacity for cooperation. It can also enhance the expertise of instructors, and serve as a useful tool in integrated educational endeavors, such as STEM/STEAM [7]-[10]. 
With the recognition of the intrinsic and extrinsic value of robotics education, robotics-related contents have not only been covered in after-school activities, but are also included in regular school subjects, including "Practical Arts" in elementary schools, and "Technology and Home Economics" and Informatics in middle and high schools. In addition to Korea, the United Kingdom recently included robotics-related contents into its "Design and Technology" subjects content to reflect changes in the digital industry [11][12]. Education can be defined as activities that instill the necessary knowledge, attitude, and competence in students to prepare them for the future [13][26]. Accordingly, robotics education can be defined as activities that instill knowledge, attitude, and competence related to the future growth of the robotics field. Since all educational objectives naturally change over time to reflect the skills in demand in a given time period, revisions to the educational contents comprising the curricula are necessary [14][15]. Changes in robotics-related educational objectives and contents in the curricula of elementary, middle, and high schools are required to accommodate the rapid developments in robotics. While robotics-related educational objectives and contents can be found in "Practical Arts" in elementary schools, "Technology and Home Economics" in middle schools, and the "Technology and Home Economics" elective in high schools, research in this area is almost non-existent. As such, this study analyzed the educational objectives and contents related to robotics in the curricula of elementary, middle, and high schools instead of vocational education. The correlation between educational objectives and contents was analyzed by time period, and future directions for robotics education were explored to ensure that the necessary knowledge, education, and competencies are instilled in students [28].

\section{Research Questions}

The purpose of this study is to analyze the trends and characteristics of the educational objectives and contents related to robotics in the curricula of elementary, middle, and high schools in Korea. The research questions are as follows.
First, what are the trends and characteristics of robotics-related educational objectives in the curricula of elementary, middle and high schools in Korea?

Second, what are the trends and characteristics of robotics-related educational contents in the curricula of elementary, middle and high schools in Korea?

Third, is there any correlation between the robotics-related educational objectives and educational contents in the curricula of elementary, middle and high schools in Korea?

\section{Methodology}

This study undertook the following procedures to analyze the robotics-related educational objectives and contents in the curricula of elementary, middle, and high schools in Korea.

First, a five-member team comprising one professor of pedagogy, one doctoral graduate in robotics, and three field experts in robotics education was formed. Through three rounds of meetings, the team developed criteria to select documents containing robotics-related educational objectives and contents from among the curricula of elementary, middle, and high schools that were available in the National Curriculum Information Center. A curriculum was considered related to robotics if it contained the word "robot," "mechatronics," "microcontroller and in/output device (including sensor and motor)," or terms such as "robot," "mechatronics," and "microcontroller and in/output device (including sensor and motor)" to enhance the understanding of the educational objectives and contents. The curricula included in the analysis were as follows: the 2007 No. 79 "Practical Arts" and "Technology and Home Economics" Curriculum announced by the Ministry of Education \& Human Resources Development[16], the 2011 No. 361 "Practical Arts" and "Technology and Home Economics" Curriculum announced by the Ministry of Education, Science and Technology in August 2011 [17], and the 2015 No. 74 "Practical Arts", "Technology and Home Economics", and Informatics Curriculum announced by the Ministry of Education in September 2015 [18][27].

Table 1. Example of classification of objectives in the taxonomy table

\begin{tabular}{|c|c|c|c|c|c|c|}
\hline \multirow{2}{*}{ Knowledge Dimension } & \multicolumn{5}{|c|}{ Cognitive process dimension } \\
\cline { 2 - 7 } & Remembering & Understanding & Applying & Analyzing & Evaluating & Creating \\
\hline Factual & & & & & & \\
\hline Conceptual & & & & & & \\
\hline Procedural & & & & & & \\
\hline Meta-Cognitive & & & & & & \\
\hline
\end{tabular}


Second, in the curricula for students of elementary, middle, and high schools, the educational objectives were expressed differently by time period as "teaching objectives," "grade objectives," "general objectives," and "achievement criteria." Considering this point, the trends and characteristics of robotics-related educational objectives were analyzed. Robotics-related educational objectives were examined based on Bloom's new taxonomy of educational objectives. First, the educational objectives were analyzed by detecting verbs and nouns; verbs were cross-matched to the six cognitive processes (remember, understand, apply, analyze, evaluate, create) and nouns were mapped to the four knowledge dimensions (factual knowledge, conceptual knowledge, procedural knowledge, meta-cognitive knowledge). Learning objectives can be classified according to original methods of teaching and evaluation, and the consistency of such classifications can be reviewed. The complex types of knowledge and related cognitive processes can be expressed in the form of a table, enabling instructors to identify disproportionalities and make improvements through the relationship between the learning objectives and related domains [19][29] The taxonomy table is useful in enhancing instructors' understanding of the curriculum, lesson planning, and the design of consistent evaluation protocols, thereby ultimately improving the quality of the teaching. In the revised version of Bloom's taxonomy of educational objectives by Anderson [20],[30], the rows and columns each represent knowledge dimensions and cognitive processes, and the cells in the table are intersections between the knowledge dimensions and cognitive processes (Table 1). All objectives can be classified using this table, and placed in the appropriate cells [21]. By applying the above methods and procedures, the educational objectives were analyzed by the author and two doctoral-degree holders in robotics-related pedagogy. First, to ensure the reliability of the results, the test-retest process was repeated three times at a certain interval until a consistency of at least $90 \%$ was obtained. To ensure inter-rater reliability, data coding was performed after providing the coders with a full explanation of the domains and units of analysis. Inter-rater agreement was more objectively verified by performing a reliability test with the responses processed on a nominal scale, which resulted in a Cronbach's $\alpha$ of 0.881 . For cases in which objectives were classified differently by the coders, they were asked to re-classify them through mutual agreement [31][32].

Third, the educational contents in the curricula of the elementary, middle, and high schools were analyzed by time period. Depending on the time period, the educational contents were expressed as "content," "content system," and "content by domain." The trends and characteristics of robotics-related contents were studied using the unit or domain names presented under "content" or the equivalent sections. If the trends proved difficult to determine based on unit names, the sub-units or educational objectives (achievement criteria), learning elements, and teaching methods were examined.

Fourth, the correlation between educational objectives and contents was examined based on the trends and characteristics analyzed.

\section{Changes in Robotics-related Educational Objectives in Elementary, Middle, and High Schools}

This study examined the trends and characteristics of robotics-related educational objectives in "Practical Arts" in elementary schools, and the curricula of middle and high schools. Robotics-related educational objectives were found in "The World of Technology" section in the "Practical Arts" category of elementary schools, "The World of Technology" section of "Technology and Home Economics" in middle schools, and "The World of Technology" section in "Technology and Home Economics" as well as the elective subject of "Engineering technology", which was changed to a subject called "General Engineering" in the high school curriculum revised in 2015. The trends and characteristics were analyzed by time period. The characteristics of the educational objectives were analyzed based on Bloom's new taxonomy of educational objectives.

In the curricula of the elementary, middle, and high schools of Korea, the word "robot" and related words first appeared in the revised national curriculum of 2007. They were mentioned as educational objectives of the mechanical engineering and technology section of "Engineering technology", an elective subject for 11th and 12th graders, under the revised curriculum of "Technology and Home Economics”. In the revised national curriculum of 2011, robotics-related educational objectives were presented in "Practical Arts" in elementary schools, "Technology and Home Economics" in middle schools, and "Technology and Home Economics" as a general optional subject, and "Engineering technology" as an advanced optional subject in high schools. However, in the revised national curriculum of 2015, robotics-related educational objectives were only found in "Practical Arts" in elementary schools and as a general elective of "Technology and Home Economics" in high schools. Such objectives were excluded from "Technology and Home Economics" subject in middle schools and "General Engineering" subject in high schools, which was the first subject to have robotics-related educational objectives. 
Table 2. Robotics-related Objectives in the KOREA National Curriculum

\begin{tabular}{|c|c|c|c|}
\hline \multicolumn{3}{|c|}{ Korea’s National Curriculum } & \multirow{2}{*}{ Objectives } \\
\hline Grade & Subject & Curriculum’s name & \\
\hline \multirow{3}{*}{$5-6$} & \multirow{3}{*}{$\begin{array}{l}\text { Practical } \\
\text { Arts }\end{array}$} & 2007-revised & None \\
\hline & & 2011-revised & $\begin{array}{l}\text { Investigate and experience robots used in everyday life. } \\
* \text { Understand simple principles behind robots used in everyday life, and } \\
\text { experience simple robots equipped with various sensors. }\end{array}$ \\
\hline & & 2015-revised & $\begin{array}{l}* \text { Understand principles and applications of robots in everyday life based } \\
\text { on case studies. } \\
* \text { Create robots equipped with various sensors. }\end{array}$ \\
\hline \multirow{3}{*}{$7-9$} & \multirow{3}{*}{$\begin{array}{l}\text { Technology and } \\
\text { Home-economics }\end{array}$} & 2007-revised & None \\
\hline & & 2011-revised & $\begin{array}{l}\text { Solve simple problems related to creating robots } \\
* \sim \text { Explain everyday applications of robots. } \\
* \text { Present creative solutions in robotics-related activities. }\end{array}$ \\
\hline & & 2015-revised & None \\
\hline \multirow[b]{3}{*}{10} & \multirow[b]{3}{*}{$\begin{array}{l}\text { Technology and } \\
\text { Home Economics }\end{array}$} & 2007-revised & None \\
\hline & & 2011-revised & $\begin{array}{l}* \sim \text { Understand basic principles, case studies, and future trends of robotics } \\
\text { and automation technology (manufacturing). }\end{array}$ \\
\hline & & 2015-revised & $\begin{array}{l}* \text { Based on new or improved products brought about by technological } \\
\text { advancements, predict the uses and future directions of the latest } \\
\text { technology (mechatronics, etc.). } \\
* \text { Investigate uses robots and communications technology in healthcare } \\
\text { and tele-medicine. }\end{array}$ \\
\hline \multirow{6}{*}{$11-12$} & \multirow{3}{*}{$\begin{array}{l}\text { Engineering } \\
\text { Technology }\end{array}$} & 2007-revised & $\begin{array}{l}\text { Understand basic knowledge and developmental directions of } \\
\text { machine-related engineering technology (robots, etc.) }\end{array}$ \\
\hline & & 2011-revised & $\begin{array}{l}\text { Understand changes resulting from automation, and the roles and functions } \\
\text { of robots in manufacturing systems } \\
\text { * Understand the roles and functions of robots in the manufacturing } \\
\text { systems of industries. }\end{array}$ \\
\hline & & 2015-revised & None \\
\hline & \multirow{3}{*}{ Information } & 2007-revised & None \\
\hline & & 2011- Revised & None \\
\hline & & 2015- revised & $\begin{array}{l}\text { * Configure the computing device (microcontroller, various I/O devices) } \\
\text { by selecting the appropriate hardware for problem solving } \\
\text { * Programming to control the operation of a physical computing device. }\end{array}$ \\
\hline
\end{tabular}

Table 2 gives an overview of robotics-related educational objectives and other educational objectives containing technology-related terms in the revised national curricula of 2007, 2011, and 2015. In the revised high school curriculum of 2015, mechatronics was presented as a learning element of the latest technology section in “Technology and Home Economics” [17] Since the field of mechatronics is related to robotics [11], it was considered a robotics-related educational objective.

Table 3 and Figure 1 compare the key concepts of the educational objectives presented in Table 2 by school and time period.

An analysis of Table 3 using Bloom's original taxonomy of educational objectives showed that $82.4 \%$ of robotics-related educational objectives associated robotics-related knowledge with cognitive domains such as “investigating," “understanding,” “explaining,” and "predicting," while $17.6 \%$ associated robotics-related functions with psychological activities such as “experiencing," “making,” and "problem-solving.”
Learning type, teaching methods, and evaluation methods can be systematically organized by classifying educational objectives according to their characteristics [22]. As such, schools have relied on Bloom's original taxonomy of educational objectives to classify and organize educational objectives. According to Figure 1, the affective domains related to robots have not been presented. However, the affective domains are naturally covered under cognitive or psychomotor domains even if they are not specified as objectives [23] and Bloom's taxonomy has been criticized for oversimplifying the way in which the nature of thinking is related to learning [24]. Another criticism is that Bloom's original taxonomy cannot fully reflect today's logical, experiential knowledge system [11]. Anderson et al. addressed the aforementioned issues by modifying Bloom's taxonomy to consider creativity and meta-cognitive knowledge, thereby adopting a dual structure comprising cognitive processes knowledge dimensions [20]. 
A Review of the 2007, 2011 and 2015 Revised Curricula

Table 3. The Key concepts of Robotics-related objectives in the KOREA National Curriculum (periods)

\begin{tabular}{|c|c|c|c|}
\hline \multirow{2}{*}{ Key concepts } & \multicolumn{3}{|c|}{ KOREA National Curriculum } \\
\hline & 2007-revised & 2011-revised & 2015-revised \\
\hline (A)Investigating case studies & & & $\checkmark$ \\
\hline (B)Explaining case studies & & $\checkmark$ & $\checkmark$ \\
\hline (C)Understanding fields of applications & & & $\checkmark$ \\
\hline (D)Understanding roles & & $\checkmark$ & \\
\hline (E)Understanding basic knowledge & $\checkmark$ & & \\
\hline (F)Explaining basic principles & & $\checkmark$ & \\
\hline (G)Understanding principles of operation & $\checkmark$ & & $\checkmark$ \\
\hline (H)Understanding functions & & $\checkmark$ & \\
\hline (I)Explaining future trends & & $\checkmark$ & \\
\hline (J)Understanding development directions & $\checkmark$ & & \\
\hline (K)Predicting development directions & & $\checkmark$ & \\
\hline (L)Experiencing simple robots equipped with various sensors & $\checkmark$ & & \\
\hline (M)Solving simple problems on creating robots & & $\checkmark$ & \\
\hline$(\mathrm{N})$ Configuring the robotics-related computing devices for problem solving & & & $\checkmark$ \\
\hline (O)Programming for control the robotics-related physical computing devices & & & $\checkmark$ \\
\hline
\end{tabular}

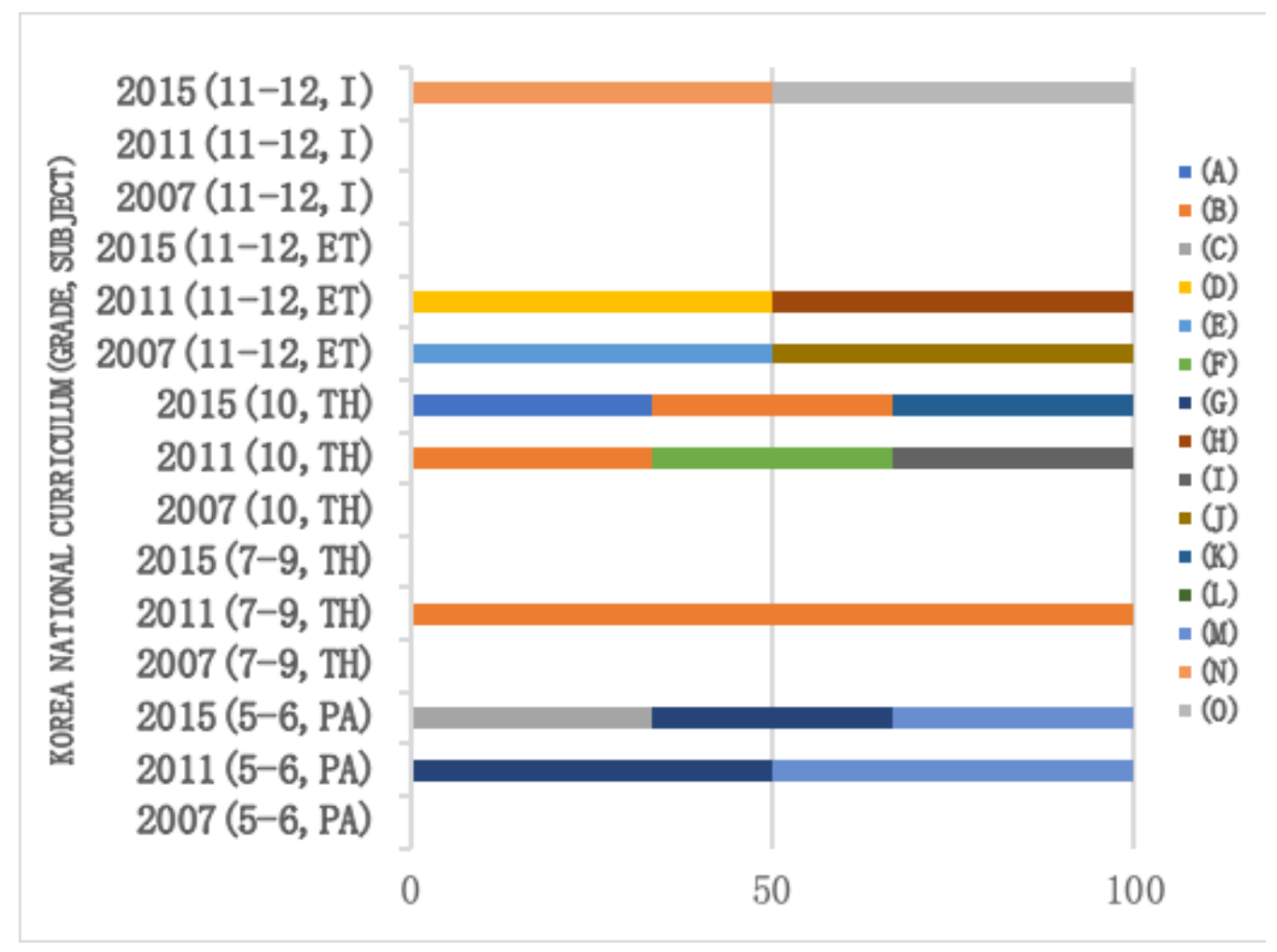

Subject: PA (Practical Arts), TH (Technology and Home Economics), ET (Engineering Technology), I (Information)

Figure 1. The Key concepts of the robotics-related objectives in the KOREA National curriculum (school and grade by curriculum)

According to Bloom's new taxonomy of educational objectives, the educational objectives can be classified into six verb-based cognitive processes: remember, understand, apply, analyze, evaluate, and create, and four noun-based knowledge dimensions of factual, conceptual, procedural, and meta-cognitive knowledge. The changes in robotics-related educational objectives based on Bloom's new taxonomy are given in Figure 2. 


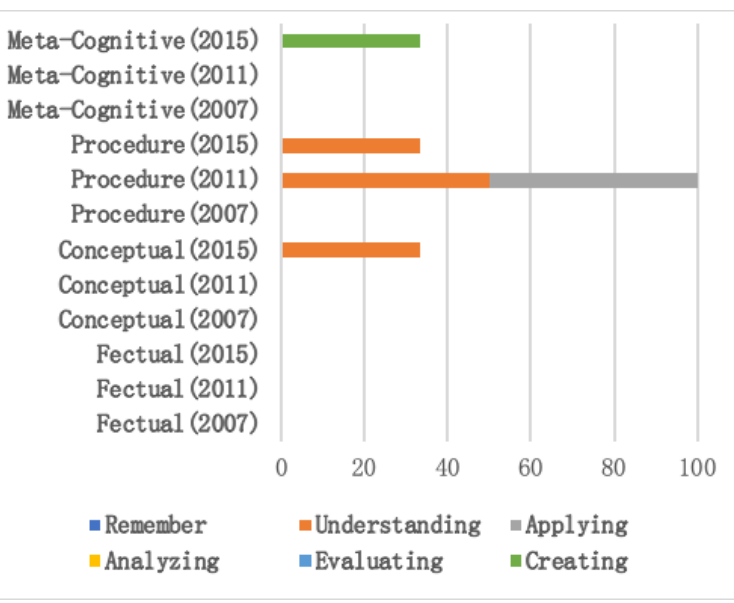

(a) Practical Arts (5-6 $\left.{ }^{\text {th }}\right)$

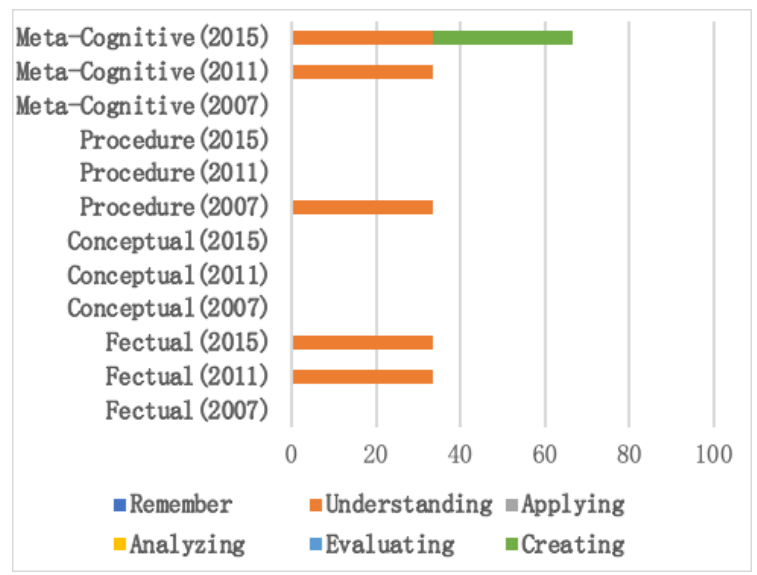

(c) Technology and Home Economics $\left(10^{\text {th }}\right)$

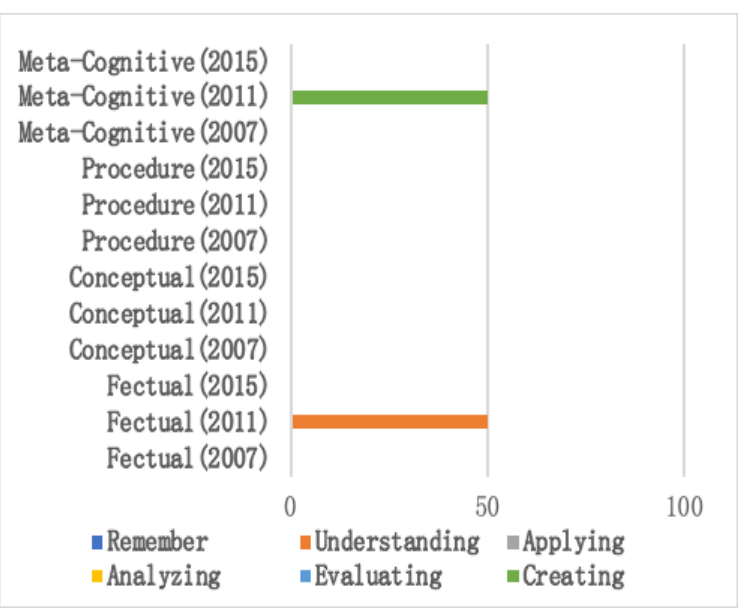

(b) Technology and Home Economics (7-9 $\left.9^{\text {th }}\right)$

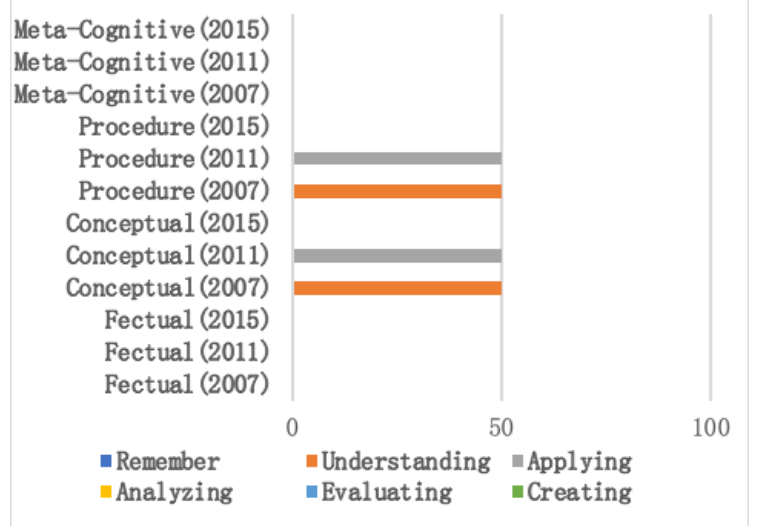

(d) Engineering Technology $\left(11-12^{\text {th }}\right)$

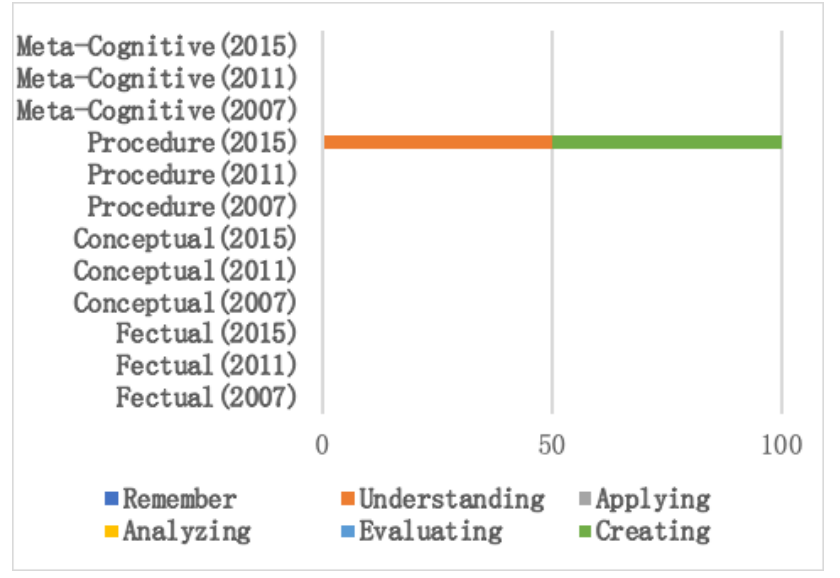

(e) Information (11-12 $\left.2^{\text {th }}\right)$

Figure 2. Trends in robotics—related objectives based on Bloom's new taxonomy of objectives by subjects and grades

Similar to Table 1, Figure 1 classifies the educational objectives into cognitive processes and knowledge dimensions. Educational objectives related to robots in "Practical Arts" and "Technology and Home Economics" subjects in elementary, middle, and high schools are not uniformly distributed, but are mostly concentrated on "understand." The most commonly associated knowledge dimensions were "conceptual knowledge” and "procedural knowledge," and those remaining were "factual knowledge" and "meta-cognitive knowledge."

The "Practical Arts" subject in elementary schools showed an increase in the emphasis on "understand" in the educational objectives compared to those of 2011. More higher order thinking skills were expected of students, with educational objectives shifting in focus from "apply" in 2011 to "create" in 2015. Simple experience-based 
activities were replaced with the making of robots, which were all tied to procedural knowledge.

In middle schools, the robotics-related educational objectives were only included in the revised curriculum of 2011. The educational objectives aimed to instill lower order thinking skills such as "understand," and higher order thinking skills such as "create." In terms of the knowledge dimension, the highest dimension of "meta-cognitive knowledge" was presented. In other words, both higher order cognitive processes and higher order knowledge were covered by the educational objectives. Although the cognitive processes and knowledge dimensions were not uniformly distributed, the objectives were desirable in that they engaged lower order cognitive processes, higher order cognitive processes, and higher order knowledge dimensions. However, these robotics-related objectives were excluded from the revised curriculum of 2015, resulting in a disconnect with the educational objectives of elementary schools.

In high schools, the educational objectives for both "Technology and Home Economics" and "Engineering technology”(“General Engineering”) engaged cognitive processes with a particular focus on "understanding." One noteworthy point is the inclusion of multiple knowledge dimensions. The revised curriculum of 2011 presented educational objectives covering "factual knowledge," "conceptual knowledge," and "procedural knowledge," while the revised curriculum of 2015 included "factual knowledge," "conceptual knowledge," and "meta-cognitive knowledge.” Despite being more intensive subjects, "Engineering technology" and "General Engineering" only covered "conceptual knowledge" and "procedural knowledge," thus failing to instill the higher order thinking skills necessary to achieving the educational objectives focused on "understanding."

Given the definition of education as activities that instill the necessary knowledge, attitude, and competence in students to prepare them for the future [13], students in the age of the fourth industrial revolution must be given opportunities to participate in activities aimed at instilling higher order thinking skills rather than those focused on developing lower order thinking skills. Unlike the educational objectives of the "Practical Arts" subject in elementary schools and "Technology and Home Economics" in middle schools, those in high schools were concentrated on "understanding." Higher order thinking skills were not included as educational objectives in high schools, where students should be more capable of critical thinking than elementary or middle school students. Conversely, the elementary school curriculum, presented robotics-related objectives aimed at instilling both lower and higher order thinking skills. Middle schools included educational objectives that engaged both lower and higher order thinking skills in the revised curriculum of 2011, but excluded such objectives in the recently revised curriculum of 2015. Robotics-related educational objectives were found only in elementary and high schools, and the lack of such objectives in middle schools highlights the need for greater consistency.

\section{Changes in Robotics-related Educational Contents in Elementary, Middle, and High School}

This study analyzes the trends and characteristics of robotics-related educational contents observed in the "Practical Arts" and "Technology and Home Economics" curricula of elementary, middle, and high schools. Curriculum documents use terms such as "area," "contents," and "contents system" to reference educational contents. To analyze the trends and characteristics of curriculum educational contents, this study examines the robotics-related contents presented in the "world of technology" in the subject area of "Practical Arts" subjects covering the "Technology and Home Economics" subjects, and in the "area," "content," and "content system" of engineering courses. For circumstances in which the observations of these sections did not provide sufficient information, the educational objectives, learning elements, teaching-learning methods, and evaluation methods in curriculum documents were studied. Robotics-related contents in the elementary, middle, and high school curricula for each period are presented in Table 4.

According to Table 5, the term "robot" or robotics-related educational contents can be found in selective intensive engineering courses for students in their second and third years of high school $\left(10^{\text {th }}-11^{\text {th }}\right.$ graders $)$ in the 2007-revised curriculum. While the contents are not indicated in the curriculum documents, their inclusion of the term "robot" as an educational objective for the first time laid the foundation for robotics education. Subsequently, in the 2011-revised curriculum, "robot" was included in the educational contents of the curriculum documents for "Practical Arts" courses in elementary schools; "Technology and Home Economics" subjects, which are part of a common curriculum for middle schools; and engineering courses, which are selective intensive courses for high school students. The term was not presented in the educational contents comprising the curriculum documents of "Technology and Home Economics" courses, which are general elective courses for high school students, but "robot and automation" was presented as an educational objective in a chapter titled "the world of future technologies," thereby including robots in teaching-learning activities. In the 2015-revised curriculum, references to robots are only found in the "Practical Arts" courses at the elementary school level, but in the "Technology and Home Economics" course at high schools, robot and robotics-related contents are mentioned in the educational objectives and learning elements, thereby allowing for related teaching-learning activities. The robotics-oriented educational contents in related chapters or curriculum can be found in Figure 3. 
Table 4. Trends of Robotics-related educational contents in the KOREAN National Curriculum for each period

\begin{tabular}{|c|c|c|c|}
\hline Grades & 2007-revised & 2011-revised & 2015-revised \\
\hline $5^{\text {th }}$ & None & \multirow{2}{*}{$\begin{array}{c}\text { Understanding of the "ROBOT" } \\
\text { (sub-unit of "Life and } \\
\text { electrical/electronics" unit) }\end{array}$} & \multirow{2}{*}{$\begin{array}{l}\text { Function and structure of the } \\
\text { "ROBOT" }\end{array}$} \\
\hline $6^{\text {th }}$ & None & & \\
\hline $7^{\text {th }}$ & None & \multirow{3}{*}{$\begin{array}{c}\text { Automation and ROBOT } \\
\text { (sub-unit of "Manufacturing technology } \\
\text { and Automation" unit) }\end{array}$} & \multirow{3}{*}{ None } \\
\hline $8^{\text {th }}$ & None & & \\
\hline $9^{\text {th }}$ & None & & \\
\hline $10^{\text {th }}$ & None & $\begin{array}{c}\text { None } \\
\text { (the Robotics-related objectives presented } \\
\text { in the "World of the future technology" } \\
\text { unit) }\end{array}$ & $\begin{array}{c}\text { None } \\
\text { (the Robotics-related contents } \\
\text { presented in the "high-technology" } \\
\text { unit) }\end{array}$ \\
\hline $\begin{array}{l}11-12^{\text {th }} \\
(* \mathrm{TH})\end{array}$ & $\begin{array}{l}\text { None } \\
\text { (the Robotics-related objectives } \\
\text { presented in the "Understanding } \\
\text { of the mechanical devices" unit) }\end{array}$ & $\begin{array}{c}\text { None } \\
\text { (the Robotics-related objectives presented } \\
\text { in the "World of the future technology" } \\
\text { unit) }\end{array}$ & None \\
\hline $\begin{array}{c}11-12^{\text {th }} \\
(* * I)\end{array}$ & None & None & $\begin{array}{c}\text { None } \\
\text { (the Robotics-related objectives } \\
\text { presented in the "Computing System" } \\
\text { unit) }\end{array}$ \\
\hline
\end{tabular}

*TH: Technology and Home Economics

**I: Information

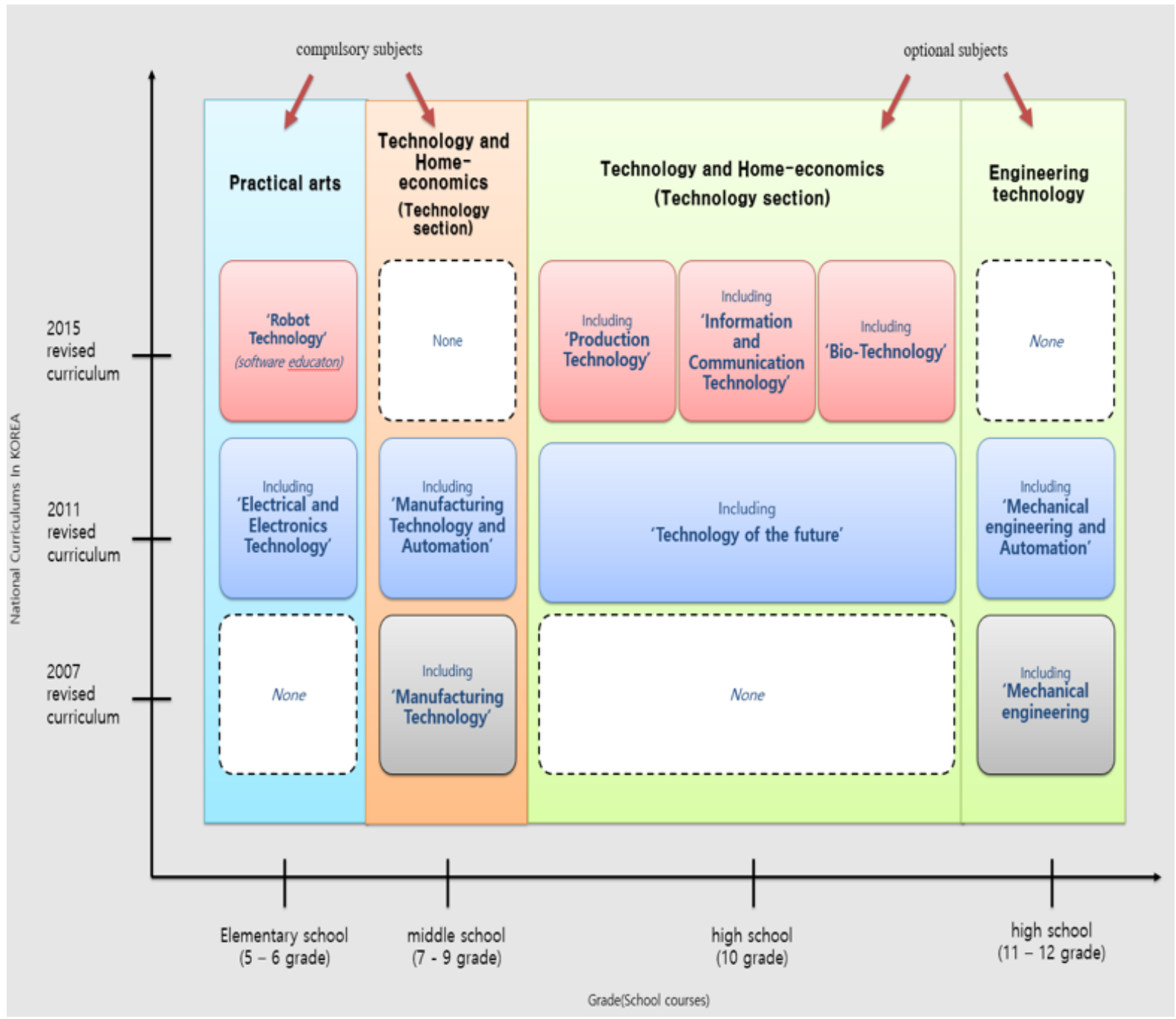

(a) Course I: The optional subject of the 11-12 grades is the "Engineering Technology" subject 


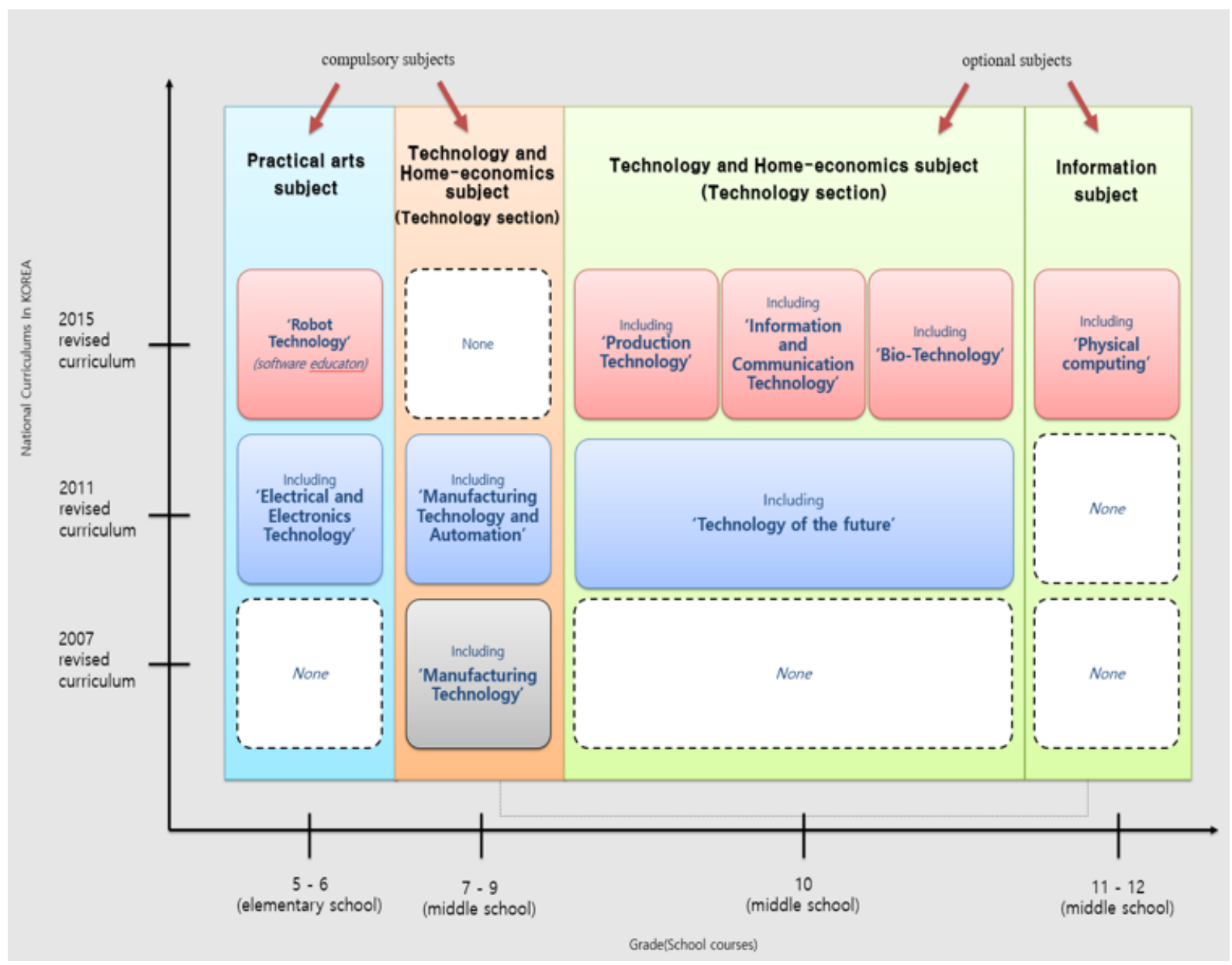

(b) Course II: The optional subject of the 11-12 grades is the "Information" subject

Figure 3. Trends in robotics—related contents by school grades

In "mechanical engineering," a selective intensive course at the high school level in the curriculum revised in 2007, references to robots first appeared in the contents of the topic, "understanding of machinery."

Robotics-related contents were first included in the "mechanical engineering" subject area under the curriculum revised in 2007. They later appeared in the "life and electronics" chapter of the elementary "Practical Arts" course, and the "manufacturing technology and automation" chapter of the "world of technologies" topic in the "Technology and Home Economics" course at the middle school level in the curriculum revised in 2011, thereby including robotics-related contents in the curricula for elementary, middle, and high school. The subject of robotics was not presented in a separate chapter in the "Technology and Home Economics" course at the high school level, but it could be confirmed that robotics-related contents were included in the curriculum, as they were found in the achievement standards for all educational contents and the teaching-learning methods under the "future technology and society" chapter. Moreover, in the engineering course, which is a selective intensive course for high school students, robot contents appeared in the "automation and mechanical engineering" subject area of the "world of engineering." Robotics-related contents were also included in the "electronics" subject area at the elementary school level, while they were included in that of "manufacturing technology" at the middle school level and that of "engineering" in engineering courses at the high school level. Thus, no sequence or continuity was evident in such curricula [25]. Under the curriculum revised in 2015, robotics-related contents were presented only for elementary school students, not in that for the middle school "Technology and Home Economics" course, the high school general elective course ("Technology and Home Economics" course), or the high school career selection course ("General Engineering"). However, robotics contents were mentioned in the curriculum, as "mechatronics" was included among the learning elements, teaching-learning methods, and notes from the "advanced manufacturing technology" contents under the "technology system" subject area of the "Technology and Home Economics" course, which is a general elective course at the high school level; the "medical technologies using robots and remote medical service" was also included in the explanations of achievement standards for the 
advanced biotechnology contents. However, it was observed that under the curriculum revised in 2015, references to robots were not included in the "General Engineering" course, the course title of which had been changed from the high school engineering course, a selective intensive (career) course that first included robots in the curriculum. Moreover, although robotics contents were included in the "electronics" subject area under the curriculum revised in 2011, such contents were presented in a separate section under the "Practical Arts" curricula revised in 2015. Additionally, the teaching-learning methods and note stipulated that "software" and "robot" should be linked when taught to students. This implies that robotics, which had been connected to machinery, electronics, manufacturing technology, and production technology in the previous curriculum, was affected by the recent emphasis on software education. In addition, the high school "Technology and Home Economics" curriculum revised in 2015 linked robots with biotechnology as well as manufacturing engineering. As such, it reflected the fact that service robots, as well as industrial robots, are now used in various fields. However, robotics is utilized not only in manufacturing technology and biotechnology but also in the transportation, construction, and information and communication technologies. Therefore, educational contents related to robotics should be included across all technology disciplines.

Robotics has been taught in the context of software in electronics courses under the elementary school "Practical Arts" curricula, in that of manufacturing technology under the middle school "Technology and Home Economics" curricula, in that of advanced manufacturing technology and biotechnology in the future technology course under the high school "Technology and Home Economics" curricula, and in the mechanical engineering subject area under the high school intensive curricula. While the term "robot" is a standalone concept, robotics is utilized in various contexts because it is an interdisciplinary subject. However, it could be confirmed that the characteristics of continuity and sequence were absent from the curricula on robotics education, as the field is not presented within a single subject under the elementary and middle school "Practical Arts" course ("Technology and Home Economics" course) curricula in Korea, but is instead presented under different individual subject areas.

\section{Robotics-related Educational Objectives at Elementary, Middle, and High Schools and Relevance of Contents}

A comparison of the trends of educational objectives and contents of the "Practical Arts" and "Technology and Home Economics” curriculum of elementary, middle, and high schools by period is presented in Table 5 .

In the case of the elementary school "Practical Arts" course, under the 2011-revised curriculum, robots are covered in the electronics chapter rather than in an independent chapter, and the educational objectives are presented as understanding the working principles and using robots to be consistent with the educational contents of "understanding robots." However, basic information or the educational objectives required to understand robots were not mentioned. Under the curriculum revised in 2015, contents on robots were presented separately from those of the 2011 curriculum, and the number of educational objectives also increased. The functions and structure of robots comprised the educational contents, and the contexts in which robots are utilized were presented to help students understand the robots' functions. The structure of the robots and the process followed for their manufacture were presented to show students the working principles of robots and meet the educational objectives. Under such a curriculum, the educational contents are interconnected with the educational objectives, allowing students to learn from a comprehensive perspective. However, the functions and structure of robots that were included as the educational contents were too advanced, such that elementary school students were unable to easily understand them. 
Table 5. Robotics-related educational objectives at elementary, middle, and high schools and relevance of contents

\begin{tabular}{|c|c|c|c|c|}
\hline \multicolumn{3}{|c|}{ National curriculum in KOREA } & \multirow[b]{2}{*}{ Contents } & \multirow[b]{2}{*}{ Objectives } \\
\hline $\begin{array}{c}\text { School } \\
\text { (gra-de) }\end{array}$ & Sub-ject & Per-iod & & \\
\hline \multirow{3}{*}{$\begin{array}{l}\text { Elementary } \\
\text { school }\left(5-6^{\text {th }}\right)\end{array}$} & \multirow[b]{3}{*}{ Practical Arts } & 2007 & None & None \\
\hline & & 2011 & Understanding robots & $\begin{array}{l}\text { - Understanding the simple working principles of } \\
\text { robots } \\
\text { - Using simple robots equipped with diverse sensors }\end{array}$ \\
\hline & & 2015 & $\begin{array}{l}\text { Functions and structure of } \\
\text { robots }\end{array}$ & $\begin{array}{l}\text { - Understanding the working principles of robots in } \\
\text { daily life } \\
\text { - Understanding the contexts in which robots are used } \\
\text { in daily life } \\
\text { - Manufacturing robots equipped with diverse sensors }\end{array}$ \\
\hline \multirow{3}{*}{$\begin{array}{c}\text { Middle } \\
\text { school }\left(7-9^{\text {th }}\right)\end{array}$} & \multirow{6}{*}{$\begin{array}{l}\text { Technology } \\
\text { and Home } \\
\text { Economics }\end{array}$} & 2007 & None & None \\
\hline & & 2011 & Automation and robots & $\begin{array}{l}\text { - Explaining where robots are used in daily life } \\
\text { - Participating in simple activities using robots }\end{array}$ \\
\hline & & 2015 & None & None \\
\hline \multirow{3}{*}{$\begin{array}{l}\text { High school } \\
\qquad\left(10^{\text {th }}\right)\end{array}$} & & 2007 & None & None \\
\hline & & 2011 & $\begin{array}{l}\text { None } \\
\text { ("Future technology and the } \\
\text { world" unit) }\end{array}$ & $\begin{array}{l}\text { - Explaining the basic principles of robots and } \\
\text { automation (manufacturing) } \\
\text { - Explaining cases of robots and automation } \\
\text { (manufacturing) } \\
\text { - Explaining the prospects of robots and automation } \\
\text { (manufacturing }\end{array}$ \\
\hline & & 2015 & $\begin{array}{c}\text { None } \\
\text { (“High technology” unit) }\end{array}$ & $\begin{array}{l}\text { - Presenting the utilization of High- technology and } \\
\text { the future prospects for development } \\
\text { - Exploring cases in which robots are used in medical } \\
\text { technology and remote medical services }\end{array}$ \\
\hline \multirow{6}{*}{$\begin{array}{c}\text { High } \\
\text { school }\left(11-12^{\text {th }}\right)\end{array}$} & \multirow{3}{*}{$\begin{array}{l}\text { Engineering } \\
\text { Technology }\end{array}$} & 2007 & $\begin{array}{l}\text { None } \\
\text { ("Understanding of } \\
\text { mechanical engineering" } \\
\text { unit) }\end{array}$ & $\begin{array}{l}\text { - Understanding the basic knowledge in the } \\
\text { machinery-related engineering discipline (robots, etc.) } \\
\text { - Understanding the future direction for development } \\
\text { of the machinery-related engineering discipline } \\
\text { (robots, etc.) }\end{array}$ \\
\hline & & 2011 & Robots and automation & $\begin{array}{l}\text { - Understanding the role of robots in the production } \\
\text { system in the industrial field } \\
\text { - Understanding the functions of robots in the } \\
\text { industrial production system }\end{array}$ \\
\hline & & 2015 & None & None \\
\hline & \multirow[b]{3}{*}{ Information } & 2007 & None & None \\
\hline & & 2011 & None & None \\
\hline & & 2015 & $\begin{array}{c}\text { None } \\
\text { (“Computing System” unit) }\end{array}$ & $\begin{array}{l}\text { - Configure the computing device (microcontroller, } \\
\text { various I/O devices) by selecting the appropriate } \\
\text { hardware for problem solving } \\
\text { - Programming to control the operation of a physical } \\
\text { computing device. }\end{array}$ \\
\hline
\end{tabular}

In the "Technology and Home Economics" course taught at the middle school level, the curriculum revised in 2011 presents two educational objectives for the educational contents of automation and robots. However, as only the term "robot" appears in the document, it seems that the curriculum lacks concreteness, and it is observed that the educational objective only establishes the goals of understanding the utilization of robots and resolving the issue of their manufacture, without providing the basic principles of robotics such as their functions and structure. Moreover, the high school "Technology and Home Economics" course covered robots as a future technology, presenting the educational objective comprising an explanation of the basic principles and cases in which robots are currently used. The course's goal was to help students understand the future world of technology. However, the curriculum revised in 2015 did not present any such educational contents, but robotics-related contents and educational objectives could be found in the learning elements and educational objectives. As so many subject areas of advanced technology exist, all of which cannot be encapsulated in the curriculum, the curriculum presented separate learning elements for different technological areas to help students understand concepts of advanced manufacturing technology and biotechnology through the utilization and future direction of such 
technologies' development. Conversely, in the high school "General Engineering" course, the educational contents and educational objectives were well-connected and structured to help students fully understand them. The curriculum revised in 2007 did not mention robots as educational contents but included the topic in the educational objective, enhancing students' understanding of machinery, and the curriculum revised in 2011 linked robotics with automation; as a result, students were able to understand robots in the production system of the industrial field. The curriculum revised in 2015 did not present any robotics-related objectives or contents.

Organizing educational contents requires continuity and appropriate sequence. However, it was found that in the "Practical Arts" and "Technology and Home Economics" curriculum, the educational objectives and contents lack such continuity and sequence.

\section{Conclusion, Summary and Suggestions}

\subsection{Conclusion and Summary}

This study analyzed the trend and characteristics of the robotics-related educational objectives and contents in the "Practical Arts" of the elementary schools and "Technology and Home Economics" of the middle and high schools curricula and the relationship between the educational objectives and contents. A summary of the study results will be presented in the conclusion.

First, the trends and characteristics of the educational objectives for "Practical Arts" in the elementary schools and "Technology and Home Economics" in the middle schools are as follows. In the elementary school, the curriculum revised in 2015 presented robotics-related educational objectives that help students acquire a higher level of reasoning skills than those presented under the curriculum revised in 2011; under the curriculum revised in 2015, the number of educational objectives in the category of "understanding" increased. In addition, compared to the educational objectives under the curriculum revised in 2011, which were restricted to procedural knowledge, the curriculum revised in 2015 presented educational objectives through which students could learn conceptual and procedural knowledge simultaneously. By moving from the educational objectives through the cognitive process of "applying” to that of "creating," educational objectives were presented under which students could develop high-level reasoning skills. In the middle school "Technology and Home Economics" curricula, the robotics-related educational objectives could be found only under the curriculum revised in 2011. The curriculum presented the educational objectives to allow students to follow the cognitive process of understanding conceptual knowledge and then using it to create by applying meta-cognitive knowledge. Under the curriculum, students could develop not only low-level reasoning skills but also those at a high level, and educational objectives were presented under which high-level types of knowledge, such as meta-cognitive, could be acquired. However, they were not presented under the curriculum revised in 2015. In the high school "Technology and Home Economics" curricula, both the curriculum revised in 2011 and that of 2015 presented only educational objectives for the cognitive process of "understanding," under which students could cultivate multi-level knowledge compared to those of the elementary and middle school curriculum. In particular, the curriculum revised in 2015 allows students to experience more diverse cognitive processes by presenting higher-level knowledge to enable their understanding of meta-cognitive knowledge. In the high school engineering curricula, educational objectives under which conceptual and procedural knowledge can be learned, as well as educational objectives at the cognitive process level of "understanding," were presented under both the curriculum revised in 2011 and that revised in 2015. In the engineering curricula, robotics-related educational objectives first appeared under the curriculum, but robotics-related educational objectives disappeared under the curriculum revised in 2015, as the course title was changed to "General Engineering".

Second, the trends and characteristics of educational contents in the elementary and middle school "Practical Arts" course ("Technology and Home Economics" course) curricula are as follows. Robotics-related contents were included in the electronics chapter in the elementary school "Practical Arts" curricula under the curriculum revised in 2011. However, that revised in 2015 presented robotics-related contents in a separate section, titled the "functions and structure of robots." Under this curriculum, the educational contents previously related to electronics were taught to students in connection with software, which is growing in importance as independent educational contents. In the middle school "Technology and Home Economics" curricula, robotics-related contents were mentioned in connection with automation and robotics as part of manufacturing technology under the curriculum revised in 2011, but no educational contents relating to the topic were presented under that revised in 2015. Under the high school "Technology and Home Economics" curricula revised in 2011, robots and automation were mentioned as part of the educational contents of the "world of future technologies," under which robotics-related contents were included in the portions covering advanced manufacturing technology and biotechnology as part of the educational contents related to advanced technologies. Under the high school engineering curricula revised in 2007, robotics-related contents were presented as part of mechanical engineering, but were introduced under the title of robots and automation in the context of the industrial production system. Robotics-related contents are presented 
in the electronics and software section in the elementary school "Practical Arts" course; as the manufacturing technology section in the middle school "Technology and Home Economics" course; as the future technologies and advanced manufacturing technology and biotechnology section in the high school "Technology and Home Economics" course; and as the mechanical engineering and production system section in the high school intensive course. As such, it can be seen that although robotics is used in every discipline given its classification as a concept and an interdisciplinary field, it is not presented in a single discipline under the "Practical Arts" course ("Technology and Home Economics" course) curriculum of the elementary, middle, and high schools.

Third, the relationships between the educational objectives and the contents are as follows. In the elementary school "Practical Arts" curricula, the educational objectives and the contents were relatively well-connected, but the educational contents under the curriculum revised in 2015 were evaluated as somewhat advanced and were therefore presented at an inappropriate level. In the middle school curriculum, objectives towards developing low-level reasoning skills were first presented, and were then followed by those focused on the acquisition of high-level reasoning skills, so it was predicted that students would have difficulty learning based on those educational contents and objectives. In the high school "Technology and Home Economics" curricula, both the curriculum revised in 2011 and that of 2015 did not offer any separate educational contents related to robotics; they only mentioned the educational objectives. Among the educational objectives presented in the future technology and the world section, the robotics-related educational objectives and contents covered in the advanced manufacturing technology and advanced biotechnology section show that the curriculum reflected the utilization of robots in a wider scope of disciplines. However, there were no contents or objectives through which students could learn high-level reasoning skills and knowledge, although their learning level is higher than that of elementary and middle school students. Moreover, in the engineering course, which represents the highest in-depth level in the "Practical Arts" and "Technology and Home Economics" curricula, no robotics-related educational contents were presented under the curriculum revised in 2007, but robotics was mentioned in the educational objectives; under the curriculum revised in 2011, robot and automation were presented as educational contents and objectives, from which it was possible to confirm their relationship. Under the curriculum revised in 2015, however, robotics-related educational objectives and contents could not be found.

Under the curriculum, robotics-related educational objectives and contents fail to secure continuity and appropriate sequence as students move to higher grades. As for educational objectives, "understanding”-centered educational objectives were presented, positioning robotics education to focus on low-level reasoning skills despite its status as an advanced technology at the convergence of diverse fields. An emphasis on high-level reasoning skills could only be found in previous elementary and middle school curriculum. As for educational contents, it was difficult to maintain educational continuity, as under the elementary, middle, and high school curricula, robotics-related chapters or content areas were included in such diverse subjects as electronics, engineering, software, manufacturing technology, and biotechnology.

Robotics is a highly-valued discipline, not only from an industrial perspective, but also from an educational viewpoint (Kim, Sung Ae and Lee, Sang Bong, 2017), so robotics contents are included in the curricula of many countries around the world, including those of the US and the UK. In Korea, robots have been mentioned in curricula since the curriculum was revised in 2007. Nonetheless, no educational consensus or academic framework dictating what should be included or emphasized in robotics-related curriculum exists. However, it is noteworthy that robots are mentioned in elementary school curriculum in Korea and robotics contents are presented in an independent chapter in the curriculum revised in 2015. Therefore, it is necessary to build a framework supporting systematic curriculum to ensure continuity and appropriate sequence in middle and high school courses.

\subsection{Suggestions}

Based on the results of this study, the following recommendations are suggested.

First, it is necessary to select robotics-related educational objectives and contents with continuity and appropriate sequence in elementary, middle, and high school curricula.

Second, as an interdisciplinary field of study, robotics can help students improve their high-level reasoning skills. Therefore, it is necessary to develop educational objectives under which students can acquire not only low-level but also high-level reasoning skills.

Third, technology education is centered on hands-on activities. Therefore, according to Bloom's Revised Taxonomy of Educational Objectives, there must be educational objectives that emphasize the cognitive process of "creating." In this regard, robotics-related educational objectives and contents must contain experiential activities to enhance students' problem-solving abilities.

Fourth, as robots are used in various disciplines, robotics education must be included in all technology-related disciplines. Moreover, robotics-related educational objectives and contents should be included in courses related to agriculture and life sciences, general engineering, maritime culture and technology, and home science, which are offered as elective courses for high school students. 
Fifth, the subject area of robotics contains machinery and electronics in addition to software, so robotics should be included in technology education. In this regard, appropriate educational objectives should be established that are consistent with the goals of robotics education when developing curriculum, and then the appropriate contents should be selected and organized to meet the objectives selected.

\section{Acknowledgements}

This paper is a reconstruction based on research presented at the $18^{\text {th }}$ International Conference on Future Information and Communication Engineering (ICFICE 2018).

\section{REFERENCES}

[1] J. G. Yeo, "Future Perspective on Robotics in Korea," in Proc. The $12^{\text {th }}$ Korea Robotics Society Annual Conference: Robotics from Imagination to Reality, 2017, p. 8.

[2] S.I. Choi, and S.J. Koh, "Distributed CoAP Handover Using Distributed Mobility Agents in Internet-of-Things Networks," Journal of Information and Communication Convergence Engineering, vol. 15, no. 1, pp. 37-42, Mar. 2017.

[3] M.C. Lee, K. Inoue, M. Tashiro, and M. Cho, "Three-Dimensional Visualization Technique of Occluded Objects Using Integral Imaging with Plenoptic Camera,” Journal of Information and Communication Convergence Engineering, vol. 15, no. 3, pp. 193-198, Sep. 2017.

[4] W. Qiong, Y. Liu, and C. Wu. "An overview of current situations of robot industry development," in Proc. $4^{\text {th }}$ Annual International Conference on Wireless Communication and Sensor Network, 2018, vol. 17, p. 6.

[5] C. J. Cho, and Y. C. Song. "The 4th Industrial Revolution Strategy and Cooperation in China, India and Singapore," World Economy Brief, vol. 8, no. 14, pp. 1-4, 2018.

[6] L.W. Santoso, R. Lim, and K. Trisnajaya, "Smart Home System Using Internet of Things," Journal of Information and Communication Convergence Engineering, vol. 16, no. 1, pp. 60-65, 2018.

[7] S. Kim, and D. Y. Chung, "A Study on the ways of Robotics programs at technology education in middle school," The Korean Journal of Technology Education, vol. 6, no. 3, pp. 127-147, 2006.

[8] S. Kim, and S. D. Jee, “A Survey on Teacher's Cognition for the Improvement of Robotics Education in Public Education,” Journal of Korea Robotics Society, vol. 6, no. 4, pp. 365-372, 2011.

[9] M. J. Mataric, N. P. Koenig, and F. S. David, "Materials for Enabling Hands-On Robotics and STEM Education,” in Proc. AAAI spring symposium: Semantic scientific knowledge integration, 2007, pp. 99-102.
[10] M. Jacek, "Some Thoughts on Robotics for Education,” in Proc. 2001 AAAI Spring Symposium on Robotics and Education, 2001.

[11] Department for Education (UK), "The national curriculum in England Framework document,” 2014.

[12] S. Yi, and S. Kim, "Objectives and contents of the 2014 revised 'Design and Technology' subject national curriculum in England,” The Korean Journal of Technology Education, vol. 17, no. 2, pp. 23-46, 2017.

[13] Ahmed, U., Zin, M. L. M., \& Majid, A. H. A. Impact of Intention and Technology Awareness on Transport Industry's E-service: Evidence from an Emerging Economy. Journal of Industrial Distribution \& Business, 7(3), 13-18. 2016.

[14] S. Yi, "Challenges and Improvement Measure of Korean Technology Education to Meet Knowledge-based Society," The Korean Journal of Technology Education, vol. 1, no. 1, pp. 15-29, 2001.

[15] M. O. Kim, and H. S. Kang, "Analysis of instructional objectives of the elementary Korean curriculum based on Bloom's revised taxonomy of educational objectives," The Journal of Curriculum Studies, vol. 30, no. 1, pp. 27-58, 2012.

[16] H. S. Lee, and H. S. Kang, "Analysis of Achievement Standards of the Korean language based on Bloom' Revised Taxonomy of Educational Objectives,” Journal of Learner-Centered Curriculum and Instruction, vol. 13, no. 4, pp. 305-325, 2013.

[17] Ministry of Education \& Human Resources Development (KOREA), "National Curriculum of Practical Arts (Technology and Home-economics) subject,” 2007.

[18] Klapproth, F., \& Martin, R. Predictors of the Drop in School Marks in Secondary School: Evidence for Effects of Students' Socio-Demographic Background. International Journal of Education and Practice, 6(3), 147-166,2018

[19] Koumje, G. F. The didactics of bilingual education: Disciplinary teaching and language. International Journal of Educational Technology and Learning, 4(1), 8-12, 2018.

[20] Kubat, U., \& Dedebali, N. C. Opinions of Science Teachers for Classroom Management. Journal of Education and e-Learning Research, 5(2), 110-117., 2018.

[21] Kyrychenko, V. Indonesias Higher Education: Context, Policy, and Perspective. Asian Journal of Contemporary Education, 2(2), 159-172, 2018.

[22] Jermsittiparsert K, Trimek J, Vivatthanaporn A. Fear of Crime among People in Muang-Ake, Lak-Hok, Muang, Pathumthani. The Social Sciences, 10(1):24-30, 2015.

[23] Lawal, O., \& Samy, M. Perception of Stakeholders in Funding of Medical Education in Nigeria. International Journal of Asian Social Science, 7(6), 521-534, 2017.

[24] Likitrattanaporn, W. A Study of Language Learning Strategies for Practical Use through the Process of Cooperative Learning. International Journal of Educational Technology and Learning, 3(1), 35-44, 2018.

[25] Luo, L., Li, P., \& Zhang, P. A Comparative Study on the Teaching Effects of TRIZ Courses for the Humanities. 
Asian Journal of Education and Training, 3(1), 25-29,2017.

[26] Ministry of Education, Science and Technology (KOREA), "National Curriculum of Practical Arts (Technology and Home-economics) subject,” 2011.

[27] Ministry of Education (KOREA), "National Curriculum of Practical Arts (Technology and Home-economics) / Information subject,” 2015.

[28] B. DeVito, and T. A. Grotzer, Characterizing in Two Science Classrooms by the Cognitive Processes Demonstrated by Student and Teacher. New York, USA: Harvard University, 2005.

[29] L. W. Anderson, D. R. Krathwohl, P. W. Airasian, K. A. Cruikshank, R. E. Mayer, P. R. Pintrich, J. Raths, and M. C. Wittrock, A Taxonomy for Learning, Teaching and Assessing: A Revision of Bloom's Taxonomy of Educational Objectives, 1st ed. New York, USA: Longman Publishing, 2001.

[30] H. S. Kang, Y. G. Choik, and C. I. Chong, “An Alternation Exploration of Bloom`s Taxonomy of Educational Objectives: On the Basis of the Teachers ' Interview," Secondary Education Research, vol. 53, no. 1, pp. 51-84, 2005.

[31] K. H, Kim, K. W. Song, and C. H. Lee, "Analysis of Learning Objectives in Invention Related Textbooks for Invention Patent Specialized High Schools Based on Bloom's Revised Taxonomy of Educational Objectives," The Korean Journal of Technology Education, vol. 17, no. 1, pp. 96-114, 2017.

[32] Ali, A., \& Haseeb, M. Radio frequency identification (RFID) technology as a strategic tool towards higher performance of supply chain operations in textile and apparel industry of Malaysia. Uncertain Supply Chain Management, 7(2), 215-226. 2019.

[33] E. W. Eisner, Ethos and Education. Scotland, UK: Scottish Consultative Council on the Curriculum, 1994.

[34] E. J. Furst, “Bloom’s Taxonomy of Educational Objectives for the Cognitive Domain: Philosophical and Educational Issues,” Review of Educational Research, vol. 51, no. 4. pp. 441-453, 1981.

[35] S. Kim, S. D. Jee, and S. Yi, "Changes of the Objectives and Contents Related to 'robots' in the Korea National Curriculums for the Elementary, Middle, and High Schools," in Proc. 2018 International Conference on future information \& communication engineering, 2018, vol. 17, no. 1 , pp. 213-214. 